Citation: Lydia Chikumbi, Milan Ščasný, Edwin Muchapondwa, Djiby Thiam (2021) Premium price for natural preservatives in wine: a discrete choice experiment. Wine Economics and Policy 10(1): 101-118. doi: 10.36253/wep9508

Copyright: @2021 Lydia Chikumbi, Milan Ščasný, Edwin Muchapondwa, Djiby Thiam. This is an open access, peerreviewed article published by Firenze University Press (http://www.fupress. com/wep) and distributed under the terms of the Creative Commons Attribution License, which permits unrestricted use, distribution, and reproduction in any medium, provided the original author and source are credited.

Data Availability Statement: All relevant data are within the paper and its Supporting Information files.

Competing Interests: The Author(s) declare(s) no conflict of interest.

\section{Premium price for natural preservatives in wine: a discrete choice experiment}

\author{
Lydia Chikumbi ${ }^{1, *}$, Milan Ščasní ${ }^{2}$, Edwin Muchapondwa ${ }^{1}$, Djiby Thiam ${ }^{1}$ \\ ${ }^{1}$ School of Economics, University of Cape Town, Rondebosch 7701, Cape Town, South \\ Africa.E-mail: chklyd001@myuct.ac.za; edwin.muchapondwa@uct.ac.za; djiby.thiam@ \\ uct.ac.za \\ ${ }^{2}$ Charles University Prague, Environmental Center, Czech Republic. E-mail: Milan.Scas- \\ ny@czp.cuni.cz \\ ${ }^{*}$ Corresponding author.
}

\begin{abstract}
The South African wine industry has recently launched the world's first 'no sulphite added' wine made from indigenous Rooibos \& Honeybush toasted wood chips. This wood chip contains antioxidant properties known to protect wine from oxidation. On the other hand, $\mathrm{SO}_{2}$ as a preservative, is often perceived by wine consumers as causing headaches and migraines. Differentiated wines based on their $\mathrm{SO}_{2}$ content may be a profitable marketing avenue for the struggling industry. We interviewed more than 600 wine consumers to investigate their perceptions of wine preservatives and preference for several wine attributes. Specifically, we use discrete choice experiments to elicit willingness to pay for the innovative alternative based on Rooibos \& Honeybush wood chips. In addition to wine preservatives, we also examine consumers' preferences for organic wine attributes and wine quality measured by a 100 -point quality score and cost. Based on the results from the mixed logit model, we find that consumers are willing to pay an additional $€ 3.53$ (R56.48) per bottle of wine with natural Rooibos \& Honeybush wood chips, while they are ready to pay $€ 1.22$ (R19.52) more for organic wine and $€ 0.10$ (R1.60) for each point on the quality score. Consumer preferences are not statistically different between red and white wine but differ considerably across consumers. In particular, those who believe $\mathrm{SO}_{2}$ in wine causes headaches are willing to pay at least three times more for replacing sulphur-based preservatives with a natural one. Marketing implications are offered for the wine industry.
\end{abstract}

Keywords: wine preservatives, willingness to pay, discrete choice experiment.

\section{INTRODUCTION}

South Africa's wines have been progressively internationally competitive, with a viable and positive trend since 1994. The wine industry is the eighth in overall volume production globally and contributes approximately $4 \%$ to the world's wine. It exports half of its produce, and its local wine per capita consumption is estimated at 7.73 litres [1]. The wine industry generates R54.96 billion annually, contributing $1.2 \%$ to South Africa's GDP in 2019; R7.17 billion in taxes to the South African government; and income for 
farmers worth R6.16 billion [1]. The wine industry plays an important role in South Africa's labour market providing over 300,000 jobs. More importantly, the industry is linked to the rest of the economy through producers' purchase of goods such as fertilizers, herbicides and pesticides, and services related to insurance, finance, research \& development and advisory. Despite the benefits rendered, however, the wine industry is under serious threat.

In recent decades, the input cost of production has increased significantly in the South African wine industry. From 2006 to 2017, a steady upward trend in input production costs raised concerns about the welfare and sustainability of the industry. The increase and changes in production input costs have negatively affected the primary producers to the extent that over a thousand grape farmers have shut down operations [2] of a total of 3,145 remaining grape farmers, $13 \%$ are producing at sustainable income levels, $44 \%$ are operating at the break-even point, and the rest are making losses. Furthermore, the area under vine cultivation has reduced drastically from 102,146 hectares in 2006 to 95,775 hectares in 2016 [2].

In response to the potential impact of uncertain events, farmers implement various risk management strategies with respect to their production plans, the available finance, physical and human capital, and the degree of aversion to risk. These risk management strategies may include (among others) crop diversification, crop insurance, effective coordination, technology and innovation. For example, innovation is widely accepted to be a driving force for agricultural development. Progressively, scientists and extension agents recognize the key role of innovative farmers and acknowledge their experiments and innovations for agricultural development [3-5] and for farming systems resilience [6,7].

It has been shown that firms' capacity to innovate, and new product development in particular, has a significant potential to improve firm performance and increase market share [8-11]. However, product innovation cannot fully achieve this goal without effective market orientation [12-14]. This may require engaging various parties in understanding customers' current and future needs and the key factors for developing and designing a new or improved product that meets those needs [15]. In line with a product innovation strategy supported by market orientation, the wine industry may explore the potential of a natural preservative for wine as an alternative, with a view to developing a new product that will increase industrial specialisation and consequently improve the competitiveness of South African wines in global wine competition
Since time immemorial, sulphur dioxide $\left(\mathrm{SO}_{2}\right)$ has been used by winemakers to preserve wine [16]. Because of its antioxidant and antibacterial properties, $\mathrm{SO}_{2}$ plays an important role in not only preventing oxidation, but also maintaining freshness [17]. It is important to note that trace amounts of (endogenous) $\mathrm{SO}_{2}$, about 10-40 ppm, i.e., $10-40 \mathrm{mg}$ per litter, are naturally formed by wine yeast during fermentation [18], but winemakers add extra $\mathrm{SO}_{2}$ throughout production [19] to prevent spoilage and enhance aging potential [17]. Thus, while too much sulphur can ruin a bouquet, wine can spoil quickly when sulphur is missing.

Although some studies believes the health effects of $\mathrm{SO}_{2}$ are overstated [20], there is overwhelming evidence that $\mathrm{SO}_{2}$ may induce adverse reactions in wine drinkers suffering from sulphite sensitivity [21-24]. A wider share of the consumer population perceives that drinking even moderate amounts of wine, particularly red varieties, triggers minor health effects, including respiratory and gastrointestinal symptoms, headaches and migraines $[16,25,26]$. It is estimated that about $1 \%$ of wine consumers are sulphite-sensitive [27].

While medical science has not reached a consensus on whether $\mathrm{SO}_{2}$ does in fact cause the reported minor health effects, public health authorities have made it mandatory for wine makers to restrict the use of sulphur in wines and display its quantity on wine bottles. This was made possible by the formation of specific legislation to control sulphite levels in final products [28]. The role of this legislation was to regulate and monitor the upper limits of sulphite and to help to standardize oenological methods in lowering sulphite concentrations in wines [29-31]. For instance, in South Africa - our study site - the Liquor Product Act 60 of 1989 requires that dry white wine produced after January 1995 may not contain more than $160 \mathrm{mg} / \mathrm{l}$ sulphur. Off-dry and sweeter wines may contain up to $200 \mathrm{mg} / \mathrm{l}$, while sulphur content is allowed to be up to $300 \mathrm{mg} / \mathrm{l}$ for late harvests. The limit for dry red wine is $150 \mathrm{mg} / \mathrm{l}$. Organic wines still contain sulphur, albeit at very low levels; however, if the level of sulphur is below $10 \mathrm{mg} / \mathrm{l}$, the product may be labelled "no sulphur added". The shelf life of these wines is necessarily limited".

\footnotetext{
${ }^{1}$ In the European Union, Regulation 1333/2008 amended by Commission Regulation 59/2014, sets a limit for total $\mathrm{SO}_{2}$ at $150 \mathrm{mg} / \mathrm{l}$ in red wines and $200 \mathrm{mg} / \mathrm{l}$ in white wines, and because some individuals are sensitive to $\mathrm{SO}_{2}$, it is mandatory to include 'contains sulphites' on the label if total $\mathrm{SO}_{2}$ is over $10 \mathrm{mg} / \mathrm{l}$ (i.e., $\mathrm{SO}_{2}$ content of not more than $10 \mathrm{mg} / \mathrm{kg}$ or $10 \mathrm{mg} / \mathrm{l}$ is not considered to be present). EC Regulation 203/2012 sets the limit for organic wines at $100 \mathrm{mg} / \mathrm{l}$ for red wines and at $150 \mathrm{mg} / \mathrm{l}$ for white and rose wines. Organic and natural winemakers restrict its usage even further. For instance, The Charter of The Authentic - Natural Winemakers' Association in the Czech Republic
} 
Even though replacement of $\mathrm{SO}_{2}$ is uncommon, there is a small number of wine-makers who produce wine with lower $\mathrm{SO}_{2}$. As noted earlier, organic wines usually contain trace amounts of sulphur. In some countries, such as the US, all organic wines are $\mathrm{SO}_{2}$-free, excluding $\mathrm{SO}_{2}$ naturally formed by wine yeast [32]. This is, however, not the case in South Africa, where wines can be classified as organic regardless of whether they contain $\mathrm{SO}_{2}$ or not. Given that the absence of added $\mathrm{SO}_{2}$ in wines can be viewed as a quality differentiation factor, and that 'no sulphite added' wines may appeal to healthconscious consumers, this study is warranted. Since the emergence of these health effects, winemakers around the world are encouraged to find alternative healthy ways to preserve wine.

Natural preservatives like yeast and other natural components of grapes and wine are used as an alternative to sulphur-based preservatives. Other alternatives to conventional wine-making include carbon dioxide additive, chemical preservation, fermentation, filtration, firming, oxidative wine making, pasteurisation, reductive winemaking, stabilisation, sterile bottling, and temperature management, hydrostatic pressure, pulsed electric fields, ultrasound radiation and ultraviolet radiation [33]. Bentonite - a pure natural absorbent swelling clay - has been used for ages to support sedimentation of yeast sludge and to bind thermosensitive proteins that prevent wine turbidity. Other nature-based substances such as plant proteins, collagens and gelatine are commonly used for wine clearing. The ongoing search for unique and innovative wine products has sparked interest in the global wine market; finding alternatives to $\mathrm{SO}_{2}$ is one such goal.

Breaking into this niche, in 2013 South Africa produced the first wine made from natural preservatives (Rooibos \& Honeybush). Rooibos (Aspalathus linearis) and Honeybush (Cyclopia) plants are indigenous to the Western and Eastern Cape provinces of South Africa $[34,35]$ and have been harvested and processed mainly to produce herbal teas [36]. Research concerning the antioxidant capacity has been conducted by the Department of Oenology at the University of Stellenbosch in collaboration with two wineries (Audacia and KWV) to utilise this indigenous wood for wine preservation [19], [36-38]. Drawing attention to consumer behaviour in the marketplace has highlighted a trend of consumers choosing healthy food products. Most consumers, particularly in recent times, are attentive to artificial additives and prefer to purchase organic foods [39]. Given

requires limits of $\mathrm{SO}_{2}$ at $90 \mathrm{ml} / \mathrm{l}$ for red and orange wines and $100 \mathrm{ml} / \mathrm{l}$ for white and rose wines, see http://vinarstvivykoukal.cz/wp-content/ uploads/2016/07/Stavek-Charta-autentistu-A2.pdf. that 'no sulphite added' wines seem attractive to healthconscious consumers, it is interesting to explore this potential niche market in depth to gauge consumers' perceptions of the importance of these wines. Determining whether consumers choose such wines is important as it would reveal whether wine players (in the South African wine context) can exploit this source of avenue in an effort to save the struggling industry. Indeed, key evidence that would inform wine players is how valuable 'no sulphite added' wine is to consumers, and what share of consumers would consider such a trait as important in their buying decisions.

Several peer-reviewed papers address consumers' willingness to pay (WTP) for wine without added $\mathrm{SO}_{2}$ [21-24]. While there is agreement about the negative effects of $\mathrm{SO}_{2}$ on health, and even that consumers are ready to pay more money to avoid added $\mathrm{SO}_{2}$ in wine, no study examines consumers' preferences for $\mathrm{SO}_{2}$ alternatives. We conduct a novel study by estimating the premium price that wine consumers are willing to pay for $\mathrm{SO}_{2}$ alternative.

To fill the research gap, our study uses a primary survey and discrete choice experiment (DCE) $)^{2}$ to analyse preferences for three qualitative non-monetary attributes of wine: natural preservatives, organic production, and quality measured by a 100-point score, and the fourth attribute is price. Specifically, we aim to answer the following four research questions: (1) Are consumers ready to pay for wines made with natural preservatives (Rooibos \& Honeybush), organic production, and with a higher quality score?; (2) Do preferences for wine colour and hence marginal willingness to pay for the three qualitative wine attributes differ for red and white wine?; (3) Since a sulphur-based preservative is perceived to trigger headaches, are consumers who believe that $\mathrm{SO}_{2}$ in wine causes headaches willing to pay more for the wine attributes, particularly for Rooibos \& Honeybush preservatives?; and, lastly, (4) Do preferences vary among various consumer characteristics such as gender, race, and the frequency of wine drinking? We use the stated preference approach to understand consumers' perceptions and, in particular, how consumers would value a wine that was produced using Rooibos \& Honeybush as a preservative for both conventional and organic production.

We find that wine consumers in South Africa are willing to pay a price premium of $€ 3.53$ per bottle of

\footnotetext{
${ }^{2}$ Although the DCE has some limitations such as hypothetical bias (see Lusk and Schroeder, 2004), it allows researchers to control for exogenous factors that may otherwise weaken the results and also ensures that the effects of each attribute on preferences are identified (Kroes and Sheldon, 1988)
} 
wine if Rooibos \& Honeybush rather than $\mathrm{SO}_{2}$ is used as a wine preservative, and this premium does not differ between red and white wine. Of 611 wine consumers interviewed, about $68 \%$ believe that consuming a moderate volume of wine causes headaches, and the same consumers are willing to pay three times more for the natural preservatives (€5.67) than those who do not think $\mathrm{SO}_{2}$ in wine causes headaches $(€ 1.82)$. The price premium for organic wine is smaller, about $€ 1.22$, and it does not differ much between the two segments. Wine quality (measured by a 100-point Quality Score) matters as well, but respondents are willing to pay only about $€ 0.10$ and $€ 0.15$ for the two segments. There is large heterogeneity in consumers' preferences.

The remainder of the paper is organised as follows. Section 2 reviews the literature. Section 3 describes the methodology and the data used for the analysis. Section 4 summarizes the empirical results, and Section 5 concludes.

\section{LITERATURE REVIEW}

There is no valuation study that examines consumers' preferences for an alternative to sulphur-based preservatives in wines. However, several studies analyse preferences for wines with 'no sulphites'added - two elicited stated preferences, one aimed at revealed preferences. Using a conjoint choice approach, Costanigro et al. [22] analyse the willingness to pay for non-sulphated wines in the US. Analysing the best-worst choices by ordered logit, they find that US consumers are, on average, willing to pay $\$ 1.23(€ 1.11)$ per bottle of wine to avoid added $\mathrm{SO}_{2}$. They also find that $34 \%$ of respondents experienced headaches after drinking wine, and these consumers are ready to pay more for wine with no sulphur, $\$ 1.23$ (€1.11). Similarly to the study by Costanigro et al. [22], D'Amico et al. [23] also use a direct survey to analyse the purchase interest of Italian wine consumers for organic wine with no added sulphur. Estimating the ordered logit, they find that the majority of Italians (54.5\%) were not willing to pay a premium for no added sulphur, and only $10 \%$ would pay a small premium. Environmental consciousness and 'wine curiosity' led consumers to pay a higher price for organic wines with no added sulphur. On the other hand, naturalness and designation of origin increased the probability of paying a premium price for wine with no added sulphur. The study also discovered that insufficient information is a barrier to accepting a higher price for organic wines and wines with no added sulphur. This study also highlights the need to educate consumers on health effects in order to obtain a positive evaluation of the healthrelated attributes of wine. Instead of stated preferences, Grogan [24] aims at revealed preferences to examine the value of added sulphur in French organic wines using an organic wine dataset from 546 wineries. Estimating the hedonic pricing model, they find that the addition of the $\mathrm{SO}_{2}$ preservative reduced the price of red organic wine by $23 \%$ for wines that were intended to be drunk immediately after purchase; however, this effect becomes positive for wines that were intended to be cellared for at least one to three years. Adding $\mathrm{SO}_{2}$ had neutral to positive effects for most white wines.

A more recent study by Amato et al. [21] analyses consumers' willingness to pay for wine bearing a $\mathrm{SO}_{2}$ free label in Italy and Spain using experimental auctions. They employed a Tobit model for the analysis. Results in both countries show that consumers who associated the headaches with drinking wines with $\mathrm{SO}_{2}$ are also willing to exchange the habitually consumed bottle of wine with a 'no-added sulphite' wine and they would even be willing to pay something extra for such wine.

In addition to research that directly examines the effect of added $\mathrm{SO}_{2}$ on wine price and consumer decisions, other studies examine consumers' preferences and willingness to pay for wines perceived to be healthier. For example, a study by Barreiro-Hurlé et al. [40] reveals a positive valuation for resveratrol-enriched wine, a health-promoting ingredient. Organic wines are also often perceived as being health-promoting [40,41], and health-conscious consumers are particularly receptive to marketing campaigns promoting natural (and organic) wines [17].

Another stream of literature focuses on organic wines $[42,43]$. These studies highlight the effect of environmental concerns, and, as Olsen et al. [44] argue, the price premium for organic wine may be viewed as the financial "self-sacrifice" made in order to protect the environment. It is important to note, though, that 'organic' is a multifaceted attribute encompassing numerous consumer values, and consumers may even have difficulty explaining why they value organic wine over other varieties [40].

Several studies aim at various intrinsic (such as sensory characteristics) and extrinsic wine attributes (such as price, grape origin, vintage, or brand). Gil and Sánchez [45] vary wine price, age, and origin and find that, in the absence of other quality cues, the origin is the most important wine attribute. Robertson et al. [46] examine the subjective knowledge about wine associated with the relative importance of four extrinsic product attributes. They find knowledge of wine age, brand, and the region of wine origin to be increasingly impor- 
tant, whilst the price of wine was the dominant attribute regardless of the level of product knowledge.

Similarly, Mueller et al. [47] use informed sensory hedonic tests to understand the interplay of wine sensory characteristics and extrinsic attributes such as packaging, price and brand awareness. With enrichment of choice experiments by the sensory tests, they were able to simulate consumers' purchase, which allowed them to examine preferences for new wines and predict their market uptake. Lockshin et al. [48] and Mtimet and Albisu [49] examine how market involvement influences the valuation of wine attributes such as brand, region of production, quality medals, and aging.

To sum up, despite relatively large literature on consumers' preferences for wine attributes, including organic quality and the non-use of $\mathrm{SO}_{2}$ as a wine preservative, literature that would elicit consumers' preferences for a natural preservative is non-existent. This study therefore fills the gap by investigating consumer preferences for Rooibos \& Honeybush (a natural preservative) and evaluates specifically whether or not, and to what extent, consumers are willing to pay for wines that are preserved by it.

\section{METHODS AND DATA}

\subsection{Sampling and implementation strategy}

Historically, black South Africans were prohibited from purchasing and consuming clear liquors, making the white consumer group the largest group of wine drinkers [50]. However, after the change of regime (postapartheid) and with the growing number of black middle class, whites are no longer the majority wine consumers. Nevertheless, there are no background statistics on wine consumer segments. For this reason, we used multistage sampling to select areas and places to conduct the interviews. In the first stage, Cape Town city was purposely chosen from the Western Cape province $^{3}$ because it has the largest number of people and wine consumers [51]. About $95 \%$ of South African wine is produced in this province. The second stage involved randomly selecting clusters of shopping malls across the city. These malls encompass retail businesses that sell wine, i.e., restaurants, liquor-stores, supermarkets and bars. The third and final stage involved randomly select-

\footnotetext{
${ }^{3}$ Western Cape is a province of South Africa located on the southwest coast of the country and has 6.6 million inhabitants, of which two-thirds live in the metropolitan area of Cape Town, which is also a provincial capital and tourist destination. The total population of South Africa is about 58 million.
}

ing wine customers who went shopping in the pre-selected shops to form the sample. Eligibility criteria included any person above age 18 (this is the legal alcohol drinking age in South Africa) and who had consumed at least a bottle of wine $(750 \mathrm{ml})$ in the last 6 months. Participants were approached by enumerators and asked if they could voluntarily take part in a wine survey for academic purposes. Five enumerators were recruited from postgraduate students enrolled at the School of Economics at the University of Cape Town, who were trained prior to pre-testing of the instrument. No incentive was offered to the survey participants. The interview was conducted in English and the enumerators used a pen-and-paper mode of interviewing.

A survey instrument was comprehensively pre-tested in two waves of testing with 44 and 52 wine consumers in the Western Cape province of South Africa during 10-14 June 2019, and 24-28 June 2019, respectively. Based on respondents' feedback, the survey instrument was modified to improve its readability and comprehension. The questionnaire consisted of four sections. The first section contained a brief explanation of the purpose of study without mentioning details of the study so as to minimise a potential framing bias. Questions regarding the wine acquisition practice were asked. The second section dealt with consumer information and knowledge about $\mathrm{SO}_{2}$ content in wine, perceived health effects, cultivar production types and quality score of wine. The discrete choice experiment was presented in the third section. In the event respondents chose no change (status quo), respondents were asked to provide their main reason in order to identify protest responses. The final section collected socio-economic and other relevant information about the respondents. To facilitate understanding and render the survey more pleasant to respondents, visual information was included (see, Figure 1).

The main survey was conducted between July 8-22, 2019 , and a total of 611 participants completed the survey. The demographic characteristics of the sample are reported in Table 1. While the sample may not be representative of the South African population, the recruiting strategy was highly successful in targeting respondents in areas where the majority of wine consumers reside. Almost everyone purchased at least a bottle of wine in a typical month. The majority of respondents $(78 \%)$ are aged $21-50$ years. There are $42 \%$ males and $51 \%$ females, while $7 \%$ choose not to provide information about their gender.

The majority of the respondents reside in Africa (80\%), some in Europe (10\%), while $4 \%$ and $3 \%$ came from Northern America and Asia, respectively, and the rest (3\%) from other parts of the world. Regarding race, 
our sample included 33\% Caucasian, 31\% African, 23\% coloured (mixed race), and the minority being Indian and Asian (5\% each). In addition, over $66 \%$ held a university degree. Median net annual household income is between R200,000 and R350,000 (€12,500-€21,875), coinciding with the average annual household income for South Africa at R270,000 [51]. However, one third of the respondents preferred not to provide information about their income.

To understand how respondents perceive $\mathrm{SO}_{2}$ in wine, we asked them several questions. First, we asked "Do you have allergies to sulphur-contained foods and beverages such as wine?", followed by the question "Do you know, or have you heard of, someone who suffers from sulphite allergies in wine?". The final and the key question was "Do you believe that drinking even moderate amounts of wine give you a headache?". About $25 \%$ of respondents reported being allergic to $\mathrm{SO}_{2}$ in foods and beverages; $61 \%$ claimed to know someone who suffers from $\mathrm{SO}_{2}$ effects. About $68 \%$ believed that drinking even a moderate volume of some type of wine may result in a headache. We name this group as 'headache', while the remaining respondents constitute the 'no-headache' group.

About $15 \%$ of the respondents drink wine almost daily, $19 \%$ drink wine several times a week, $27 \%$ and $22 \%$ drink wine at least once a week or a fortnight, and only $5 \%$ drink wine rarely. When analysing observed preference, we name 'heavy drinkers' as those who drink wine almost daily or several times a week, and 'light drinkers' as those who drink wine once a month or less often (61\% of our sample). 'Heavy' wine drinkers' and 'light' wine drinkers constitute approximately $34 \%$, and $17 \%$, of the sample size, respectively.

When making their choice, our survey participants had in their mind a wine with a price of about 195 Rand $(\mathrm{std}=116)$ for a $(750 \mathrm{ml})$ bottle, with a minimum at 35 Rand and a maximum at 900 Rand. In euro equivalents, our respondents, on average, typically buy a bottle of wine for $€ 11.5$ (std=6.85), with $€ 2.07$ and $€ 53$ for the cheapest and the most expensive wine, respectively. This price also set the cost of the status-quo wine to which a price premium is added for the alternative wines.

\subsection{Experimental design}

Designing a DCE involves the selection and combination of the attributes and their levels to construct the alternatives included in hypothetical choice situations presented to respondents [52]. Respondents are then asked to think about the situation in which they would be making their choices. Identification of the attributes in our experiment was facilitated by the literature
Table 1. Socio-demographic characteristics of the sample $(n=611)$.

\begin{tabular}{lc}
\hline Variable & Percent \\
\hline Gender & \\
Males & $42 \%$ \\
Females & $51 \%$ \\
\hline Age & \\
$18-20$ & $4 \%$ \\
$21-30$ & $32 \%$ \\
$31-40$ & $24 \%$ \\
$41-50$ & $22 \%$ \\
$51-60$ & $15 \%$ \\
$61-70$ & $3 \%$ \\
\hline Education
\end{tabular}

\section{Education}

High (secondary) school $\quad 12 \%$

Some technical certificate/diploma $\quad 19 \%$

Bachelor's degree $\quad 22 \%$

Honours degree $\quad 18 \%$

Professional/Master degree $\quad 16 \%$

Doctorate degree $\quad 11 \%$

Income

R50,000 and less (€3,125 and less) $\quad 12 \%$

$\mathrm{R} 50,000$ to R100,000 (€3,125 - €6,250) 5\%

$\mathrm{R} 100,000$ to R150,000 (€6,250 - €9,375) $\quad 5 \%$

$\mathrm{R} 150,000$ to $\mathrm{R} 200,000(€ 9,375-€ 12,500) \quad 5 \%$

R200,000 to R350,000 (€12,500 - €21,875) 7\%

$\mathrm{R} 350,000$ to $\mathrm{R} 500,000(€ 21,875-€ 31,250) \quad 9 \%$

R500,000 to R750,000 (€31,250 - €46,875) $\quad 8 \%$

$\mathrm{R} 750,000$ to R1,000,000 (€46,875 - €62,500) $\quad 5 \%$

$\mathrm{R} 1,000,000$ to $\mathrm{R} 2,000,000(€ 62,500-€ 125,000) \quad 5 \%$

$\mathrm{R} 2,000,000$ and more (€125,000 and more) $\quad 4 \%$

I prefer not to answer $\quad 33 \%$

Wine Consumption

Almost daily $\quad 15 \%$

Several times a week $\quad 19 \%$

Once a week $\quad 27 \%$

Once a fortnight $\quad 22 \%$

Once a month $12 \%$

Very rarely $\quad 5 \%$

\begin{tabular}{ll}
\hline Headache & $68 \%$
\end{tabular}

review addressing particularly recent studies [21-24]. In line with the state-of-the-art recommendations for stated preference studies $[53,54]$, the design of our study was also based on findings from qualitative pre-testing that we conducted in focus groups with wine consumers from the Cape Town area. The qualitative pre-testing confirmed the suitability of the survey design and ensured the relevance and understanding of the attributes.

For our study, the alternatives were described using a pre-defined set of attributes with levels that were 
Table 2. Attributes and levels of the discrete choice experiment.

\begin{tabular}{|c|c|c|}
\hline Attribute & No. of levels & Levels \\
\hline Preservatives & 2 & $\mathrm{SO}_{2}$-based, Rooibos \& Honeybush \\
\hline Type of viticulture production & 2 & Conventional, Organic \\
\hline Wine quality score & 6 & $60,75,82,88,92,100$ \\
\hline Price (increase compared to what you usually buy) & 5 & $\begin{array}{l}\text { Rands: } 0,30,45,60,75 \\
\text { (EUR equivalent: } 0,1.77,2.66,3.54,4.43 \text { ) }\end{array}$ \\
\hline
\end{tabular}

experimentally varied around the level expected by the respondents. We used four attributes: Wine preservative $\left(\mathrm{SO}_{2}\right.$-based vs. Rooibos \& Honeybush), Type of viticulture production (conventional vs. organic), Wine quality score, and Price (see, Table 2).

There are two types of wine preservatives in our choice experiment: Rooibos \& Honeybush and $\mathrm{SO}_{2}$ -based preservative. Type of viticulture production may either be organic (wine produced using organically grown grapes) or conventional (wine produced using grapes grown with added chemicals, i.e., fertiliser, pesticide). The two viticulture types were included to allow a direct comparison of the valuation of conventional wines preserved with $\mathrm{SO}_{2}$ versus conventional wines preserved with Rooibos \& Honeybush, and again organic wines preserved with $\mathrm{SO}_{2}$ versus organic wines preserved with Rooibos \& Honeybush. This distinction allows the assessment of the influence of Rooibos \& Honeybush in both viticulture production types.

Wine quality score is defined according to the Wine Spectator [55] scores, whose expert ratings are recognised globally. Specifically, these scores are defined accordingly as 95-100, classic: a great wine; 90-94, outstanding: a wine of superior character and style; 85-89, very good: a wine with special qualities; 80-84, good: a solid, well-made wine; 75-79, mediocre: a drinkable wine that may have minor flaws; and not recommended wine graded by 50-74 points. Quality levels also represent our proxy for a wide range of attributes, i.e., brand name, taste, origin, which would otherwise make evaluation bulky had we included them in the experiment. We use the point-values of the quality score to avoid uncertainty, as described in Table 2.

Lastly, price was defined as the extra cost (premium) respondents are asked to pay in addition to the price they usually pay for a $750 \mathrm{ml}$ bottle of wine. While the decision to pay a premium price for using Rooibos \& Honeybush and other attributes in wine is essentially driven by the cost and benefits derived from its consumption, the individual choice is difficult to anticipate because of such reasons as information deficit and perceived or experienced health effects. The wine price was shown as an increment of what a consumer typically pays for a bottle of wine, and the premium included nominal Rand values: 30, 45, 60, and 75, and Euro equivalents are also shown on the cards in brackets. ${ }^{4}$ In relative terms, the offered bids represented $15 \%$ to $38 \%$ of the average price of the status-quo wine. Since the bids were offered in absolute values, wine price premiums ranged between $3.3 \%$ and $214 \%$, with the mean at $37 \%$.

The choice task included three alternatives, with one referred to as wine that is typically purchased (i.e., the status quo). The status quo option described a typical wine sold on the South African market (in the Western Cape province); that is, a $750 \mathrm{ml}$ bottle of conventional wine with $\mathrm{SO}_{2}$-based preservatives, graded by a 75-point quality score, whilst the price in the status quo was respondent-specific. Specifically, before the valuation part, we asked each respondent to state "What is the average price for which you typically buy a bottle of wine most often?". We found that respondents typically paid approximately $€ 11.5$ for a bottle of wine (std.= $€ 6.85$ ), with a minimum at $€ 2.1$ and a maximum at $€ 53$. An example of a choice card as presented to our respondents is shown in Figure 1. We then asked "Which of the three alternatives do you prefer?", and we repeated this valuation question four times for each different choice situation.

Since preference for red wine and white wine may differ, we elicited consumers' preferences for red and white wines in two separate choice tasks. The order in which consumers' preferences for red or white wine were elicited was assigned to each respondent at random. ${ }^{5}$

Using NGENE software, we generate a Bayesianefficient design. The Bayesian approach for optimal experimental design has become more prominent in the literature [53,56-63] due to its ability to optimise design criteria that are functions of the posterior distribution and can easily be tailored to the experiments' objectives. Further, the framework provides a formal approach

\footnotetext{
${ }^{4}$ We used the exchange rate 0.059 Euro per Rand, based on the South Africa Reserve Bank prevailing rate at the time. www.resbank.co.za ${ }^{5}$ Our experiment contained another split-sample treatment in which we expressed price either in Rand or as a percentage change from the status quo level. In this paper, we use only responses with the price in Rand.
} 
Figure 1. Example of a choice situation.

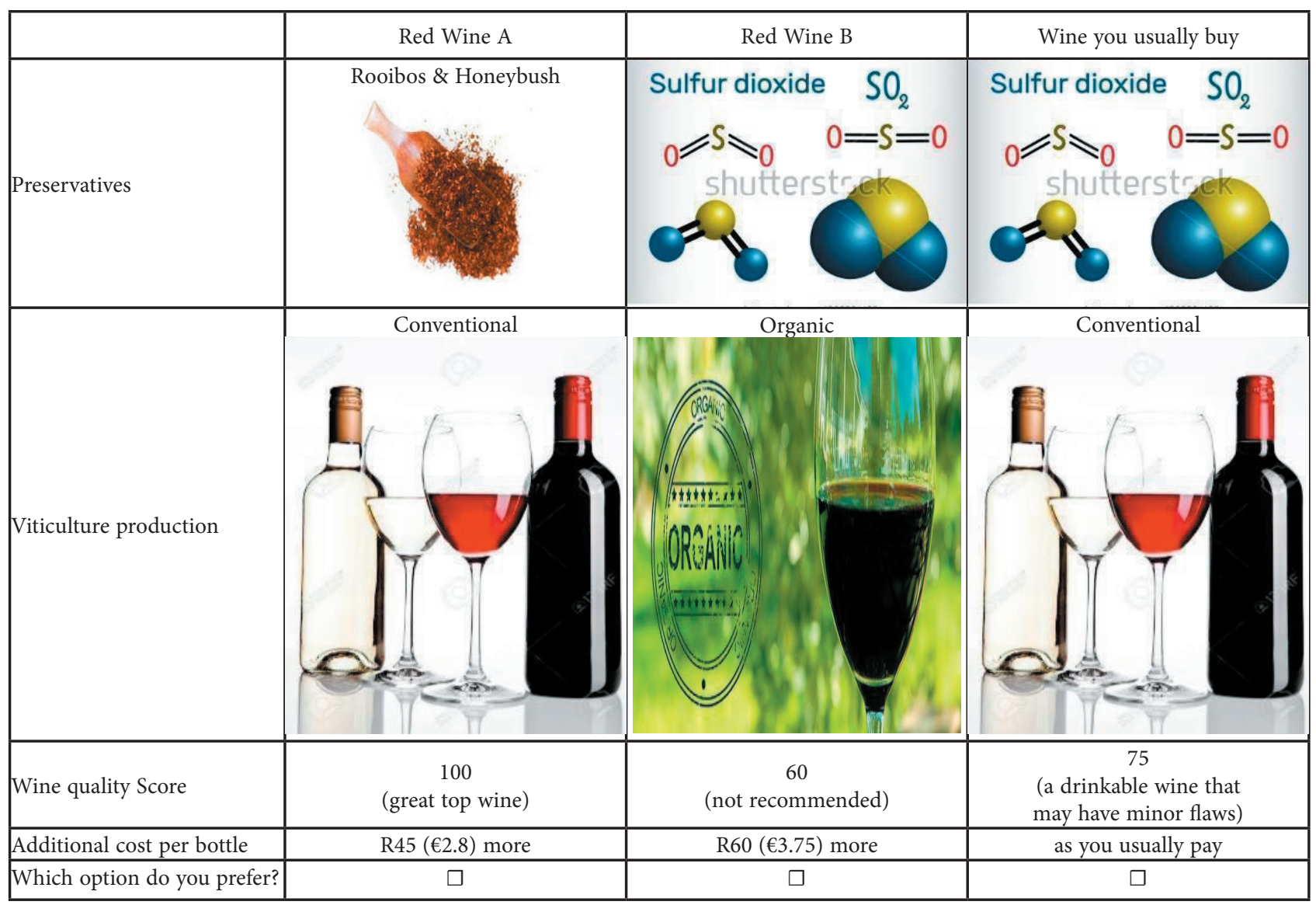

for incorporating parameter uncertainties and prior information into the design process via prior distributions, and provides a unified approach for joining these quantities with the model and design criterion [64]. Our design contains twelve unique choice combinations grouped into three, giving us four choice cards per each respondent. In total, we obtain 2,444 responses (from 611 respondents) for both choice tasks, one for white wine and another for the red wine experiment.

\subsection{Econometric framework}

The discrete choice experiments (DCE) technique has grown in popularity since its introduction by Batsell and Lodish [65] and Louviere and Hensher [66]. The use of the technique has been extended to many disciplines such as transportation, agriculture and environment, telecommunications, marketing and human health [21,40,48,67-75]. Applications also include conservation of wine varieties or valuation of wild crop conservation
$[76,77]$. While DCE has limitations on hypothetical bias [78], it allows the study of products that are not yet available on the market [79] or policies that are not yet implemented [80,81]. Experimental designs not only allow researchers to control for exogenous factors that may otherwise weaken the results, but also ensure that the effects of each attribute on preferences are identified [82].

The choice model relies on the random utility theory [83], which assumes that individual $n$ chooses the alternative $j$ in choice situation $t$ with regard to the highest utility:

$$
U_{n j t}=X_{n j t} \alpha_{n}+\beta_{n} \cdot\left(Y_{n}-P R I C E_{n j t}\right)+\varepsilon_{n j t}
$$

where $X$ represents a vector of alternative specific attributes (PRESERVATIVES, VITICULTURE PRODUCTION, QUALITY SCORE), Y is income, PRICE is the price of wine, the vector of coefficients $\alpha$ and coefficient $\beta$ are estimated and is a stochastic component identically and independently distributed with a constant variance $k_{n}{ }^{2}\left(\pi^{2} / 6\right)$, with $k_{n}{ }^{2}$, being an individual-specific 
scale parameter. Instead of separately estimating the parameters for each respondent, we follow a common practice and assume that the parameters follow specific distributions, which leads to the mixed logit model [84].

Note that the coefficients are indexed by individuals' $n$, allowing for (unobserved) preference heterogeneity. In fact, as a consequence of taste and people's concerns, consumers may respond differently to different wine attributes, leading in turn to heterogeneity with respect to individuals' expected net benefit and hence WTP for 'no sulphite added' wine. We accommodate such heterogeneity by employing econometric models that accommodate both the observable and unobservable component of individual utility from offered alternatives.

Mixed logit with all factors random, freely and fully correlated is estimated using maximum simulated likelihood technique [84] in STATA 16. An individual will choose alternative $j$ if $U_{n j t}>U_{n k t}$, for all $k \neq j$, and the probability that alternative $j$ is chosen from a set of $C$ alternatives is given by:

$P(j \mid C)=\frac{\exp \left(X_{n j t} \alpha_{n}+\beta_{n} \cdot\left(Y_{n}-P R I C E_{n j t}\right)\right)}{\sum_{k=1}^{C} \exp \left(X_{n k t} \alpha_{n}+\beta_{n} \cdot\left(Y_{n}-P R I C E_{n k t}\right)\right)}$

The usual procedure is to estimate the distribution of the utility coefficients (i.e., the model in preferencespace) and then to estimate the willingness-to-pay as a ratio of two utility parameter estimates, as $-\frac{\widehat{\alpha}}{\widehat{\hat{\beta}}}$.

In our alternative specification, we are interested to know whether preference for specific consumer segments differ. For this purpose, we fit the random utility model, additive in parameters, as follows:

$U_{n j t}=X_{n j t} \alpha_{1 n}+S \times X_{n j t} \alpha_{2}+\left(\beta_{1 n}+\beta_{2} \cdot S\right) \cdot\left(Y_{n}-P R I C E_{n j t}\right)+\varepsilon_{n j t}$

where $S$ is a vector of dummies to describe specific segments such as: people who believe that drinking even moderate amount of wine causes headache ('headache', see Table 4), race (African, Caucasian) and gender (female); see Table 5 and for frequency of wine consumption (heavy drinker, light drinker); see Table 6 to control for observed preference heterogeneity. We assume the coefficient for the interaction terms to be fixed, which allows us to measure the difference in preference for the respective consumer segment and given attribute from the random mean. ${ }^{6}$ Assuming the indi-

\footnotetext{
${ }^{6}$ We note that the main (random) effect in these MXL models represent the utility of consumers in the baseline group, while fixed coefficients for all interactions between the wine attribute and consumer characteristics measures the differences in the utility of given segments from the utility of the baseline group.
}

rect utility function is additive in its attributes, the final WTP estimate for segments $S$ in the specification is given as $-\left(\frac{\widehat{\alpha 1}+\widehat{\alpha 1} \cdot S}{\widehat{\beta 1}+\widehat{\beta 2} \cdot S}\right)$.

We also assume this specification to explore preference heterogeneity in wine colour, pooling the data from the two sub-samples. Since we do not find preference for the attributes to differ between red and white wines, see Table A1, we estimate all mixed logit models with pooled data. WTP are estimated by the delta method, using the nlcom STATA command.?

\section{ESTIMATION RESULTS}

Table 3 presents the results for the mixed logit model estimated in the preference space with all factors random and freely correlated. We pool the data, without distinguishing wine colour. All coefficients are statistically significant at any convenient level and have expected signs, conforming to a priori expectations. It implies that respondents are willing to pay a premium for each of the three wine attributes, and the likelihood of purchasing a bottle of wine is decreasing with the increase in price. We also discover large unobserved preference heterogeneity for each of the four random attributes, indicated by the large and strong statistically significant standard deviations of the means.

WTP estimates are presented in Table 4, column (1). For Rooibos \& Honeybush natural-based preservatives, respondents are willing to pay $€ 3.53$ per bottle, while the marginal price for organic winemaking is $€ 1.22$, a finding consistent with the idea that organic and $\mathrm{SO}_{2}$ added' wines are differentiated attributes, though Rooibos \& Honeybush evokes a richer and more complex set of values. These findings are consistent with a study by Costanigro et al. [22] who found $34 \%$ of resppomdents were affected by sulphite in wine. Based on a rank ordered logit estimation of best-worst choices, headache syndrome sufferers are willing to pay a ceteris paribus premium of $\$ 1.23$ per bottle to avoid added sulfites. However, results show that headache sufferers are willing to pay more for wines without added sulphites than for organic wines. WTP for each point of the Quality Score is at $€ 0.09$ per $750 \mathrm{ml}$ bottle of wine. Comparing the average price of wine that respondents had in mind when stating values, i.e., 200 Rand or $€ 11.85$, the premium comprises $30 \%$ of the wine price for a Rooibos \& Honeybush-based preserv-

\footnotetext{
${ }^{7}$ STATA command nlcom applies the delta method to compute the variance, standard error, Wald test statistic, etc., of the transformations. It is designed for functions of the parameters and takes nonlinear transformations of the estimated parameter vector from some fitted model.
} 
Table 3. Parameter estimates, MXL, pooled.

\begin{tabular}{lcc}
\hline & $\begin{array}{c}\text { Means } \\
(\text { s.e })\end{array}$ & $\begin{array}{c}\text { Standard deviations } \\
(\text { s.e })\end{array}$ \\
\hline rooibos & $2.5031^{* * *}$ & $3.3848^{* * *}$ \\
& $(0.2420)$ & $(0.3090)$ \\
organic & $0.8659^{* * *}$ & $1.7663^{* * *}$ \\
& $(0.1842)$ & $(0.2740)$ \\
quality & $0.0663^{* * *}$ & $1.0969^{* * *}$ \\
& $(0.0091)$ & $(0.0115)$ \\
price & $-0.7087^{* * *}$ & $1.9161^{* * *}$ \\
& $(0.0783)$ & $(0.0838)$ \\
\hline likelihood & -1833.6175 & \\
LR Chi ${ }^{2}$ & 1130.57 & \\
No. obs. & 7,332 & \\
$r$ (respondents) & 611 & \\
$k$ (parameters) & 14 & \\
\end{tabular}

Notes: ${ }^{*},{ }^{* *}$, and ${ }^{* * *}$ indicate the significance of the WTP mean estimates at $10 \%, 5 \%$, and $1 \%$. Standard errors are provided in parentheses. All random parameters are fully correlated, with 1000 draws for simulations.

ative, and $10 \%$ for organic wine, about $0.8 \%$ per each point in the Quality Score.

When comparing the difference between wine colour, we find no difference in preferences for the quality attributes between red and white wine (see MXL estimates in Table 1A in Appendix). WTP estimates are reported in Table 1A, Panel B. Although quality and organic production seem to be valued slightly more for red wine, clearly, neither of the two WTP estimates is statistically different. ${ }^{8}$

When we control for differences in preferences for consumers who believe that $\mathrm{SO}_{2}$ in wine causes headaches (see MXL estimate in Table A2 in the Appendix), we find willingness to pay for natural preservatives (Rooibos \& Honeybush) as well as for wine quality is at least three-times larger than for consumers who do not believe so: $€ 5.67$ vs. $€ 1.82$ for rooibos, and $€ 0.151$ vs. $€ 0.045$ for the quality score in Table 4 , whilst their WTP for organic wines does not statistically differ from the other: $€ 1.53$ vs. $€ 0.93$, with Wald $=1.28$ and p-value=.2572). See Table 4, column (2) for 'headache' consumers and column (3) for the reference group with 'no headache' consumers. We conclude that, at the margins, individuals who believe their health may be affected by $\mathrm{SO}_{2}$ in wine are also more sensitive to wine additives

${ }^{8}$ WTP for Rooibos \& Honeybush preservatives is $€ 3.71$ for red and $€ 3.43$ for white wine (Wald statistics is 0.16 , and $\mathrm{p}=0.6928$ ); WTP for the organic attribute is $€ 1.21$ and $€ 1.09$, respectively (Wald $=0.07$, $\mathrm{p}=0.7949)$; and WTP for 1-point in the quality score is $€ 0.093$ for red and $€ 0.088$ for white wine (Wald $=0.05, \mathrm{p}=0.8316$ ).
Table 4. Willingness to pay estimates per bottle of wine, means in EUR (see parameter estimates for the headache segment in Appendix A2).

\begin{tabular}{lccc}
\hline & $\begin{array}{c}\text { Pooled data } \\
(1)\end{array}$ & $\begin{array}{c}\text { Headache } \\
(2)\end{array}$ & $\begin{array}{c}\text { No 'Headache' } \\
(3)\end{array}$ \\
\hline rooibos & $3.5317^{* * *}$ & $5.6704^{* * *}$ & $1.8190^{* * *}$ \\
& $(0.3683)$ & $(0.9253)$ & $(0.2979)$ \\
organic & $1.2217^{* * *}$ & $1.5306^{* * *}$ & $0.9301^{\star * *}$ \\
quality & $(0.2650)$ & $(0.4893)$ & $(0.2547)$ \\
(per QS point) & $0.0937^{\star * *}$ & $0.1506^{* * *}$ & $0.0449^{* * *}$ \\
\hline
\end{tabular}

Notes: ${ }^{*},{ }^{* *}$, and ${ }^{* * *}$ indicate the significance of the WTP mean estimates at $10 \%, 5 \%$, and $1 \%$. Standard errors are provided in parentheses. Wald statistics for the quality test of the WTP means for headache vs. no headache segment is $15.79(\mathrm{p}=0.0001)$ for rooibos; $1.28 \mathrm{p}=0.2572)$ for organic; and $13.92(\mathrm{p}=0.0002)$ for quality.

and are ready to pay a higher premium for wines perceived to be healthier and of a higher quality.

We estimated several mixed models, following eq. (3), to explore observed preference heterogeneity with respect to gender, race, and wine consumption frequen$\mathrm{cy}^{9}$. Table 5 presents the WTP estimates based on MXL model with the interactions with gender (female) and race (being African, and Caucasian), with non-female, Asian and Coloured as the reference category. As a reminder, since we assume the additive specification of the MXL model, the fixed coefficients for the interaction terms measure the difference in the utility from the random mean (see MXL result in Table A3 in the Appendix).

We find that females value organic wines more than males, Africans value Rooibos \& Honeybush preservatives less than Caucasians, while the preferences of Caucasians do not differ from other races (those included in the reference category). This is expected considering that, on average, Caucasians and Africans in South Africa are at opposite ends of wealth and income distribution, with other race placed in between. WTP estimates reported in Table 5 show that non-African males will pay approximately $€ 4.8$ for rooibos-based preservatives, while non-African females are willing to pay $€ 3.8$ to avoid $\mathrm{SO}_{2}$ added to wine.

African males and females are willing to pay much less: $€ 2.7$ and $€ 2.2$, respectively. Interestingly, only females are willing to pay for organic attributes; about

\footnotetext{
${ }^{9}$ Parameter estimates and tests are compiled in the Appendix. Controlling for other socio-economic variables (e.g., income, education, and other wine-measuring preferences) resulted in no significant differences in preferences and are not reported here. These results are available upon request.
} 
Table 5. Willingness to pay estimates per bottle of wine, by gender and race, means in EUR.

\begin{tabular}{|c|c|c|c|c|c|c|}
\hline & $\begin{array}{c}\text { male }+ \\
\text { other race }\end{array}$ & $\begin{array}{c}\text { male }+ \\
\text { Caucasian }\end{array}$ & $\begin{array}{l}\text { male }+ \\
\text { African }\end{array}$ & $\begin{array}{c}\text { female } \\
+ \text { other race }\end{array}$ & $\begin{array}{c}\text { female } \\
+ \text { Caucasian }\end{array}$ & $\begin{array}{l}\text { female } \\
+ \text { African }\end{array}$ \\
\hline rooibos & $\begin{array}{c}4.7533^{* * *} \\
(0.9426)\end{array}$ & $\begin{array}{c}4.8661^{* * *} \\
(1.1957)\end{array}$ & $\begin{array}{l}2.677^{\star * *} \\
(0.5751)\end{array}$ & $\begin{array}{c}3.7979^{* * *} \\
(0.6707)\end{array}$ & $\begin{array}{c}3.7561^{\star * *} \\
(0.7999)\end{array}$ & $\begin{array}{l}2.207^{\star * *} \\
(0.4353)\end{array}$ \\
\hline organic & $\begin{array}{c}0.3100 \\
(0.5277)\end{array}$ & $\begin{array}{l}1.2791^{\star} \\
(0.6759)\end{array}$ & $\begin{array}{c}0.5492 \\
(0.4316)\end{array}$ & $\begin{array}{l}1.2303^{\star *} \\
(0.4534)\end{array}$ & $\begin{array}{c}2.1276^{\star * *} \\
(0.6145)\end{array}$ & $\begin{array}{l}1.2588^{\star *} \\
(0.3624)\end{array}$ \\
\hline $\begin{array}{l}\text { quality } \\
\text { (QS point) }\end{array}$ & $\begin{array}{c}0.0945^{\star * *} \\
(0.0247)\end{array}$ & $\begin{array}{c}0.1532^{* * *} \\
(0.0372)\end{array}$ & $\begin{array}{c}0.0638^{* * *} \\
(0.0187)\end{array}$ & $\begin{array}{c}0.0794^{* * *} \\
(0.0198)\end{array}$ & $\begin{array}{c}0.1240^{* * *} \\
(0.0265)\end{array}$ & $\begin{array}{c}0.0560^{\star * *} \\
(0.0147)\end{array}$ \\
\hline
\end{tabular}

Notes: ${ }^{*}{ }^{* *}$, and ${ }^{* * *}$ indicate the significance of the WTP mean estimates at $10 \%, 5 \%$, and $1 \%$. Standard errors are provided in parentheses.

$€ 2.1$ and $€ 1.3$ for Caucasians and Africans, respectively, while WTP for organic wines for males is not statistically distinguishable from zero, with the exception of male Caucasians, who are willing to pay a similar amount as African or other race females, but this estimate is only weakly significant. Males are, however, ready to pay more than females for wines with higher a Quality Score: $€ 0.077$ compared to $€ 0.056$ for Africans, and $€ 0.095$ compared to $€ 0.079$ for the other race), except for Caucasian males and females, who are actually willing to pay the same premium of $€ 0.12$.

Last, we analyse the differences in preferences for consumers who differ in their wine consumption frequency (see MXL results in Table A4 in the Appendix). We find that heavy drinkers would pay more for natural preservatives than light drinkers: $€ 5.28$ vs $€ 3.21$, organic attributes $€ 1.96$ vs $€ 0.72$, and quality score $€ 0.14$ vs $€ 0.11$. Heavy drinkers seem to care more about wine additives and are willing to pay a premium for natural preservatives, organic attributes and high quality score for wine. Light wine drinkers care less about organic

Table 6. Willingness to pay estimates per bottle of wine for Heavy vs Light wine drinkers, means in Euro.

\begin{tabular}{lcc}
\hline & Heavy drinkers & Light drinkers \\
\hline natural & $5.2811^{* * *}$ & $3.2056^{* * *}$ \\
& $(1.1534)$ & $(0.7842)$ \\
organic & $1.9583^{* * *}$ & 0.7247 \\
& $(0.6592)$ & $(0.5167)$ \\
quality & $0.1420^{* * *}$ & $0.1055^{* * *}$ \\
(QS point) & $(0.0333)$ & $(0.0265)$ \\
\hline
\end{tabular}

Notes: 'Heavy drinker' is a consumer who drinks wine at least several times a week, and 'light drinkers' is a consumer who drinks wine once a month or less often. ${ }^{*},{ }^{* *}$, and ${ }^{* * *}$ indicate the significance of the WTP mean estimates at $10 \%, 5 \%$, and $1 \%$. Standard errors are provided in parentheses. Wald statistics for the quality test of the WTP means for heavy vs. light segment is 2.24 $(p=0.1345)$ for rooibos; $2.40(p=0.1215)$ for organic; and 0.83 $(\mathrm{p}=0.3629)$ for quality. attributes which are statistically not significant. See WTP estimates in Table 6.

\section{DISCUSSION AND CONCLUSIONS}

More than half of the sample of 611 wine respondents from South Africa believes that drinking even moderate amounts of some type of wine causes headaches. A discrete choice experiment was conducted to explore the preferences of consumers in the Cape Town area for natural preservatives, organic wine, and quality measured by a 100-point Quality Score, and price attributes. This study is novel in that it estimates the premium price for not having added $\mathrm{SO}_{2}$ in wine by substituting the conventional wine preservative with Rooibos \& Honeybush - a natural preservative. This is the first analysis of its kind. We find that consumers from the Cape Town area are willing to pay about $€ 1.2$ per bottle for organic winemaking. Only Caucasian males are willing to pay for the organic quality and, on average, they are willing to pay as much as non-Caucasian females (€1.3), while Caucasian females are willing to pay $€ 2.1$ per bottle of wine for organic winemaking. Wine quality matters as well: on average, consumers are ready to pay $€ 0.10$ per each point on the Quality Score.

With regard to the key attribute - Rooibos \& Honeybush preservatives - consumers are willing to pay even more, on average $€ 3.5$, though males are willing to pay slightly more than females. Caucasian males will pay $€ 4.8$, which is almost double what African males will pay (€2.7). Caucasian females will pay $€ 3.7$ compared to African females who are ready to pay $€ 2.2$.

With regard to other studies, Amato et al. [21] find that Italian and Spanish wine drinkers will pay $€ 1.19$ and $€ 1.57$, respectively, to avoid added $\mathrm{SO}_{2}$. Similarly, Costanigro et al. [22] found $34 \%$ of respondents were affected by s2ulphite in wine. Based on a rank ordered logit estimation of best-worst choices, headache syndrome sufferers are willing to pay a ceteris paribus pre- 
mium of $\$ 1.23$ per bottle to avoid added sulfites. However, results show US wine consumers are willing to pay approximately $€ 1.19$ more per bottle of wine. It is important to note that the previous studies relied on a hypothetical $\mathrm{SO}_{2}$-free alternative and hence they did not use real preservatives as in our case (i.e., using natural the preservatives of Rooibos \& Honeybush).

Since using $\mathrm{SO}_{2}$ as a wine preservative is very likely associated with adverse health effects, we investigated whether those who believe in these effects are also ready to pay higher premiums for healthier wines. We find that these consumers are indeed willing to pay at least three times more for an $\mathrm{SO}_{2}$-free natural preservative and quality scoring than those who do not believe so. They are also ready to pay for organic winemaking, but their premium is only two thirds higher. The importance of these differences is even more significant if we consider the high percent $(68 \%)$ of respondents who believe $\mathrm{SO}_{2}$ causes headaches in our sample.

We found no difference in preferences between the colour of wine (red or white); however, willingness to pay for the three wine attributes differ between red and white wines.

Heavy drinkers would pay more for natural preservatives in wine than light drinkers. This is a good message for winemakers since the high investment cost induced by introducing the new natural preservative may be recovered faster.

Our findings confirm that consumers' decisions to purchase a bottle of wine in South Africa are more influenced by natural preservatives and organic attributes rather than a higher quality score. Our findings present a significant contribution, at least in the South African context, to understanding preference and hence a niche for the natural preservative market. The share of respondents who believe $\mathrm{SO}_{2}$ causes headaches is astonishingly large and their preference for wine with less adverse health effects is also strong. These consumers represent an apparent and potentially important market segment for the wine industry and wine producers interested in wine product differentiation. Although this study targets South African wine consumers, these findings are useful for other wine-producing countries and regions. Further research could investigate whether our findings for South African consumers also hold in other regions.

Based on our findings, we recommend that the wine industry should provide greater clarity regarding organic winemaking standards. In particular, it should clarify what constitutes organic wine, perhaps by emulating the US standard that regards organic wine as wine made without added sulphur. It is clear, though, that respond- ents are aware about natural preservatives and are in tune with the natural/organic movement for healthier living. As there is no strong scientific consensus on whether $\mathrm{SO}_{2}$ in wine causes headaches, investigations in medical research seeking to establish the root cause of headaches promises significant rewards for the wine industry.

Before embarking on investment, wineries should consider the additional costs involved with Rooibos of Honeybush alternatives and compare them with the expected premium for 'no sulphite added' wines. Our empirical study provides the industry with the first evidence of consumers' acceptance of a novel natural wine preservative and, more specifically, how wine consumers may respond.

To fully understand consumer behaviour in relation to natural preservatives, more effort should be put into determining the factors that impact wine-consumer choice. Understanding these factors can provide a better targeted marketing strategy suitable for capturing consumer preference for natural preservatives in wine. Needless to say, the preferences of a wider sample should be investigated. In this sense, the relatively small sample size $(\approx 600)$ and narrow geographic extent (the Cape Town metropolitan area) are the main limitations of our study. Nevertheless, our results are in line with previous literature on "no sulphite added" but are silent about sulphur alternatives as in our case study. Our study also supports the Wine Industry Strategic Exercise (WISE) 2025 Strategy, particularly on the theme of "Technological and innovation". ${ }^{10}$ The discovery of natural preservatives in wine making has the potential to further boost the South African wine industry's competitiveness locally and abroad.

\section{ACKNOWLEDGMENTS}

Financial support provided by the Czech Science Foundation grant number 19-26812X. All authors also acknowledge financial support from the European Union's H2020-MSCA-RISE project GEMCLIME-2020 under GA 681228 for their secondments.

\section{REFERENCE}

[1] SAWIS, "South Africa Wine Industry Information Systems, Annual Report," 2020, [Online]. Available: http://www.sawis.co.za/info/annualpublication.

\footnotetext{
${ }^{10}$ The WISE strategy was launched by the South African Wine and Brandy Company in 2015 to create a comprehensive industry-wide strategic exercise that would help transform the wine industry to become more competitive internationally by 2025 .
} 
[2] VinPro, "Cost guide for grape production in the wine industry.," 2018, [Online]. Available: https:// sales.vinpro.co.za/product/vinpro-cost-guide/.

[3] R. Chambers and L. A. Thrupp, Farmer first: farmer innovation and agricultural research. Karthala Editions, 1994.

[4] L. Klerkx and C. Leeuwis, "Matching demand and supply in the agricultural knowledge infrastructure: Experiences with innovation intermediaries," Food Policy, vol. 33, no. 3, pp. 260-276, 2008.

[5] A. Reij, C. and Waters-Bayer, "Farmer innovation in Africa: a source of inspiration for agricultural development," 2014.

[6] G. Fischer, M. M. Shah, and H. T. Van Velthuizen, "Climate change and agricultural vulnerability," 2002.

[7] R. Milestad, I. Darnhofer, and P. Taylor, "Building Farm Resilience: The Prospects and Challenges of Organic Farming Building Farm Resilience: The Prospects and Challenges of Organic Farming," J. Sustain. Agric., vol. 0046, no. November 2013, pp. 37-41, 2008, doi: 10.1300/J064v22n03.

[8] C. M. Banbury and W. Mitchell, "The effect of introducing important incremental innovations on market share and business survival," Strateg. Manag. J., vol. 16, no. S1, pp. 161-182, 1995.

[9] R. E. Caves and P. Ghemawat, "Identifying mobility barriers," Strateg. Manag. J., vol. 13, no. 1, pp. 1-12, 1992.

[10] T. R. Low, David R., Chapman, Ross L. and Sloan, "Deakin Research Online Online," 2007, Interrelat. between Innov. Mark. Orientat. SMEs, Manag. Res. news, vol. 30, no. 12, pp. 878-891., vol. 30, no. 12, pp. 878-891, 2007.

[11] S. A. Zahra and J. G. Covin, "Business strategy, technology policy and firm performance," Strateg. Manag. J., vol. 14, no. 6, pp. 451-478, 1993.

[12] K. Atuahene-Gima, "Market orientation and innovation," J. Bus. Res., vol. 35, no. 2, pp. 93-103, 1996.

[13] J. K. Han, N. Kim, and R. K. Srivastava, "Market orientation and organizational performance: is innovation a missing link?", J. Mark., vol. 62, no. 4, pp. 30-45, 1998.

[14] S. Erdil, O. Erdil, and H. Keskin, "The relationships between market orientation, firm innovativeness and innovation performance," J. Glob. Bus. Technol., vol. 1, no. 1, pp. 1-11, 2004.

[15] A. K., Kohli, and B. J. Jaworski (1990). "Market orientation: the construct, research propositions, and managerial implications.," J. Mark., vol. 54(2), pp. 1-18, 1990.
[16] M. R. Lester, "Sulfite sensitivity: significance in human health.," J. Am. Coll. Nutr., vol. 14, no. 3, pp. 229-232, 1995.

[17] J. Goode and S. Harrop, Authentic wine: toward natural and sustainable winemaking. Univ of California Press, 2011.

[18] C. Liu, R. Chen, and Y.-C. Su, "Bactericidal effects of wine on Vibrio parahaemolyticus in oysters," $J$. Food Prot., vol. 69, no. 8, pp. 1823-1828, 2006.

[19] A. W. Burgstahler and M. A. Robinson, "Fluoride in California wines and raisins," Fluoride, vol. 30, no. 3, pp. 142-146, 1997.

[20] H. Vally and P. J. Thompson, "Role of sulfite additives in wine induced asthma: single dose and cumulative dose studies," Thorax, vol. 56, no. 10, pp. 763-769, 2001.

[21] M. Amato, P. Ballco, B. López-Galán, T. De Magistris, and F. Verneau, "Exploring consumers' perception and willingness to pay for 'Non-Added Sulphite' wines through experimental auctions: A case study in Italy and Spain," Wine Econ. policy, vol. 6, no. 2, pp. 146-154, 2017, doi: 10.1016/j. wep.2017.10.002.

[22] M. Costanigro, C. Appleby, and S. D. Menke, "The wine headache: Consumer perceptions of sulfites and willingness to pay for non-sulfited wines," Food Qual. Prefer., vol. 31, no. 1, pp. 81-89, 2014, doi: 10.1016/j.foodqual.2013.08.002.

[23] M. D’Amico, G. Di Vita, and L. Monaco, "Exploring environmental consciousness and consumer preferences for organic wines without sulfites," J. Clean. Prod., vol. 120, pp. 64-71, 2016, doi: 10.1016/j.jclepro.2016.02.014.

[24] K. A. Grogan, "The value of added sulfur dioxide in French organic wine," Agric. Food Econ., vol. 3, no. 1, pp. 1-25, 2015, doi: 10.1186/s40100-0150038-1.

[25] D. J. Gaiter and J. Brecher, "Why do I get headaches from wine," Wall Str. J., 2000.

[26] S. Robin, "What are the causes of a wine headache," Livestrong. Retrieved from, 2010.

[27] R. Papazian, "Sulphites, safe for most, dangerous for some: Department of Health and Human Services," 1996.

[28] A. Rossi and F. Fusco, "Wine Index of Salubrity and Health (WISH): an evidence-based instrument to evaluate the impact of good wine on well-being," Int. J. Wine Res., vol. 11, pp. 23-37, 2019.

[29] N. D. A. EFSA, "Panel (EFSA Panel on Dietetic Products, Nutrition and Allergies), 2014," Sci. Opin. Eval. allergenic foods food ingredients Label. Purp. EFSA J., vol. 12, no. 11, p. 3894, 2014. 
[30] L. Granchi, M. Budroni, D. Rauhut, and G. Zara, "Wine Yeasts and Consumer Health," in Yeasts in the Production of Wine, Springer, 2019, pp. 343373.

[31] W. Kontaxakis, E., Trantas, E., and Ververidis, "Resveratrol: A Fair Race Towards Replacing Sulfites in Wines.," vol. 25(10), p. 2378, 2020.

[32] Alcohol and Tobacco Tax and Trade Bureau, "Alcohol and Tobacco Tax and Trade Bureau," 2014. [Online]. Available: http://www.ttb.gov/wine/winelabeling.

[33] V. Falguera, M. Forns, and A. Ibarz, "UV-vis irradiation: An alternative to reduce $\mathrm{SO} 2$ in white wines?," LWT-Food Sci. Technol., vol. 51, no. 1, pp. 59-64, 2013.

[34] J. Du Toit, E. Joubert, and T. J. Britz, "Honeybush teaa rediscovered indigenous South African herbal tea," J. Sustain. Agric., vol. 12, no. 2-3, pp. 67-84, 1998.

[35] E. Small and P. M. Catling, "Blossoming treasures of biodiversity: 27. Cannabis-dr. Jekyll and mr.hyde," Biodiversity, vol. 10, no. 1, pp. 31-38, 2009, doi: 10.1080/14888386.2009.9712635.

[36] E. Joubert, M. Manley, and M. Botha, "Evaluation of spectrophotometric methods for screening of green rooibos (Aspalathus linearis) and green honeybush (Cyclopia genistoides) extracts for high levels of Bio-active compounds," Phytochem. Anal. An Int. J. Plant Chem. Biochem. Tech., vol. 19, no. 2, pp. 169-178, 2008.

[37] B. Rankine, Making Good Wine, 184, Macmillan, Australia. Reyneke,. Making Good Wine, 184, Macmillan, Australia. Reyneke, 2004.

[38] B. B. Rudd, "Berry Bros. \& Rudd Ltd," 2016. [Online]. Available: http://www.bbr.com/wineknowledge/faq-faults.

[39] L. C. Hoffman, M. Jones, N. Muller, E. Joubert, and A. Sadie, "Lipid and protein stability and sensory evaluation of ostrich (Struthio camelus) droëwors with the addition of rooibos tea extract (Aspalathus linearis) as a natural antioxidant," Meat Sci., vol. 96, no. 3, pp. 1289-1296, 2014.

[40] J. Barreiro-Hurlé, S. Colombo, and E. Cantos-Villar, "Is there a market for functional wines? Consumer preferences and willingness to pay for resveratrol-enriched red wine," Food Qual. Prefer., vol. 19, no. 4, pp. 360-371, 2008.

[41] C. Fotopoulos, A. Krystallis, and M. Ness, "Wine produced by organic grapes in Greece: using means-end chains analysis to reveal organic buyers' purchasing motives in comparison to the nonbuyers," Food Qual. Prefer., vol. 14, no. 7, pp. 549566, 2003.
[42] Remaud, H., Mueller, S., Chvyl, P. and Lockshin, "Do Australian wine consumers value organic wine?", 2008.

[43] A. P. Antonazzo, M. Fiore, P. La Sala, and F. Contò, "Assessing perceptions of wine tourists on organic wine," Econ. Agro-Alimentare, 2015.

[44] J. Olsen, L. Thach, and L. Hemphill, "The impact of environmental protection and hedonistic values on organic wine purchases in the US," Int. J. Wine Bus. Res., 2012.

[45] J. M. Gil and M. Sánchez, "Consumer preferences for wine attributes: a conjoint approach," Br. Food J., 1997.

[46] J. Robertson, C. Ferreira, and E. Botha, "The influence of product knowledge on the relative importance of extrinsic product attributes of wine," J. wine Res., vol. 29, no. 3, pp. 159-176, 2018.

[47] S. Mueller, P. Osidacz, L. Francis, and L. Lockshin, "The relative importance of extrinsic and intrinsic wine attributes: Combining discrete choice and informed sensory consumer testing," in Refereed paper 5th international conference of the academy of wine business research, 2001.

[48] L. Lockshin, W. Jarvis, F. d'Hauteville, and J.-P. Perrouty, "Using simulations from discrete choice experiments to measure consumer sensitivity to brand, region, price, and awards in wine choice," Food Qual. Prefer., vol. 17, no. 3, pp. 166-178, 2006, doi: https://doi.org/10.1016/j.foodqual.2005.03.009.

[49] N. Mtimet and L. M. Albisu, "Spanish wine consumer behavior: A choice experiment approach," Agribus. An Int. J., vol. 22, no. 3, pp. 343-362, 2006, [Online]. Available: www.interscience.wiley. com.

[50] L. Z. B. Ndanga, A. Louw, and J. Van Rooyen, "AMERICAN ASSOCIATION OF WINE ECONOMISTS," 2009. [Online]. Available: www.wine-economics.org.

[51] StatsSA, "Mid-year population estimates," 2019, [Online]. Available: http://www.statssa.gov.za/publications/.

[52] D. Hoyos, "The state of the art of environmental valuation with discrete choice experiments," Ecol. Econ., vol. 69, no. 8, pp. 1595-1603, 2010, doi: 10.1016/j.ecolecon.2010.04.011.

[53] R. J. Johnston et al., "Contemporary guidance for stated preference studies," J. Assoc. Environ. Resour. Econ., vol. 4, no. 2, pp. 319-405, 2017.

[54] K. J. Boyle, "Contingent valuation in practice", in $A$ primer on nonmarket valuation, Springer, 2017, pp. 83-131. 
[55] Wine Spectator, "Wine Spectator," 2020, [Online]. Available: https://www.winespectator.com/.

[56] B. Amzal, F. Y. Bois, E. Parent, and C. P. Robert, "Bayesian-optimal design via interacting particle systems," J. Am. Stat. Assoc., vol. 101, no. 474, pp. 773-785, 2006.

[57] M. C. J. Bliemer, J. M. Rose, and S. Hess, "Approximation of Bayesian efficiency in experimental choice designs," J. Choice Model., vol. 1, no. 1, pp. 98-126, 2008.

[58] M. C. J. Bliemer and A. T. Collins, "On determining priors for the generation of efficient stated choice experimental designs," J. Choice Model., vol. 21, pp. 10-14, 2016, doi: 10.1016/j.jocm.2016.03.001.

[59] C. S. L. Dias et al., "A Status Quo Review of Climate Change and the Agriculture Sector of the Western Cape Province," Ecosyst. Serv., vol. 8, no. 1, pp. 1-10, 2016, doi: 10.1017/CBO9781107415324.004.

[60] C. Han and K. Chaloner, "Bayesian experimental design for nonlinear mixed-effects models with application to HIV dynamics," Biometrics, vol. 60, no. 1, pp. 25-33, 2004.

[61] X. Huan and Y. M. Marzouk, "Simulation-based optimal Bayesian experimental design for nonlinear systems," J. Comput. Phys., vol. 232, no. 1, pp. 288-317, 2013.

[62] P. Müller, D. A. Berry, A. P. Grieve, and M. Krams, "A Bayesian decision-theoretic dose-finding trial," Decis. Anal., vol. 3, no. 4, pp. 197-207, 2006.

[63] S. Ferrini and R. Scarpa, "Designs with a priori information for nonmarket valuation with choice experiments: A Monte Carlo study," J. Environ. Econ. Manage., vol. 53, no. 3, pp. 342-363, 2007.

[64] E. G. Ryan, C. C. Drovandi, J. M. McGree, and A. N. Pettitt, "A review of modern computational algorithms for Bayesian optimal design," Int. Stat. Rev., vol. 84, no. 1, pp. 128-154, 2016.

[65] R. R. Batsell and L. M. Lodish, "A model and measurement methodology for predicting individual consumer choice," J. Mark. Res., vol. 18, no. 1, pp. $1-12,1981$.

[66] J. J. Louviere and D. Hensher, "Design and Analysis of Simulated Choice or Allocation Experiments in Travel Choice Modeling.", Transp. Res. Rec., vol. XX, no. November, pp. 11-17, 1982.

[67] J. M. Rose and M. C. J. Bliemer, "Constructing efficient stated choice experimental designs," Transp. Rev., vol. 29, no. 5, pp. 587-617, 2009.

[68] C. Contini, F. Boncinelli, F. Gerini, G. Scozzafava, and L. Casini, "Investigating the role of personal and context-related factors in convenience foods consumption," Appetite, vol. 126, pp. 26-35, 2018.
[69] A. Alberini, M. Ščasný, and A. Bigano, "Policy- v. individual heterogeneity in the benefits of climate change mitigation: Evidence from a stated-preference survey," Energy Policy, vol. 121, 2018, doi: 10.1016/j.enpol.2018.07.008.

[70] F. Boncinelli, A. Dominici, F. Gerini, and E. Marone, "Consumers wine preferences according to purchase occasion: Personal consumption and gift-giving," Food Qual. Prefer., vol. 71, pp. 270-278, 2019.

[71] A. M. Poveda, M. R. Pérez, M. M. B. Mollá-Bauza, and L. M.-C. Martínez, "Determination of the surplus that consumers are willing to pay for an organic wine," Spanish J. Agric. Res., no. 1, pp. 43-51, 2005.

[72] F. Verneau, C. J. Griffith, L. Agnoli, R. Capitello, and D. Begalli, "Behind intention and behaviour: factors influencing wine consumption in a novice market," Br. Food J., 2016.

[73] L. E. R. Blackie and P. J. Cozzolino, "Of blood and death: A test of dual-existential systems in the context of prosocial intentions," Psychol. Sci., vol. 22, no. 8, pp. 998-1000, 2011.

[74] S. Mueller, L. Lockshin, Y. Saltman, and J. Blanford, "Message on a bottle: The relative influence of wine back label information on wine choice," Food Qual. Prefer., vol. 21, no. 1, pp. 22-32, 2010.

[75] T. de Magistris, A. G. Royo, and L. M. A. Aguado, "Wine consumers preferences in Spain: an analysis using the best-worst scaling approach," Spanish J. Agric. Res., no. 3, pp. 529-541, 2014.

[76] N. Tyack and M. Scasny, "Estimating the Social Value of Specific Crop Diversity Conservation Plans: Do Czechs Care More About Conserving Hop, Wine or Fruit Tree Varieties?", Charles University Prague, Faculty of Social Sciences, Institute of Economic ..., 2020.

[77] N. Tyack and M. Ščasný, "Social valuation of genebank activities: Assessing public demand for genetic resource conservation in the czech republic," Sustainability, vol. 10, no. 11, p. 3997, 2018.

[78] T. C. Lusk and Jayson L. Schroeder, "Are Choice Experiments Incentive Compatible? A Test with Quality Differentiated Beef Steaks," Am. J. Agric. Econ., vol. 86(2), pp. 467-482, 2004.

[79] M. Ščasný, I. Zvěřinová, and M. Czajkowski, "Electric, plug-in hybrid, hybrid, or conventional? Polish consumers' preferences for electric vehicles," Energy Effic., vol. 11, no. 8, pp. 2181-2201, 2018.

[80] A. Alberini and M. Ščasný, "The benefits of avoiding cancer (or dying from cancer): evidence from a four-country study," J. Health Econ., vol. 57, pp. 249-262, 2018. 
[81] M. Ščasný, I. Zvěřinová, M. Czajkowski, E. Kyselá, and K. Zagórska, "Public acceptability of climate change mitigation policies: a discrete choice experiment," Clim. Policy, vol. 17, no. sup1, pp. S111S130, 2017.

[82] E. P. Kroes and R. J. Sheldon, "Stated Preference Methods: An Introduction," J. Transp. Econ. Policy, vol. 22, no. 1, pp. 11-25, 1988, [Online]. Available: http://www.jstor.org/stable/20052832.

[83] D. McFadden and P. Zarembka, "Frontiers in econometrics." Academic Press New York, 1974.

[84] D. Revelt and K. Train, "Mixed logit with repeated choices: households' choices of appliance efficiency level," Rev. Econ. Stat., vol. 80, no. 4, pp. 647-657, 1998.

\section{APPENDIX}

Table A1. Estimation results, MXL with colour interactions.

Panel A - Parameter estimates

\begin{tabular}{lccc}
\hline & $\begin{array}{c}\text { Mean } \\
(\mathrm{s} . \mathrm{e})\end{array}$ & $\begin{array}{c}\text { SD } \\
(\mathrm{s} . \mathrm{e})\end{array}$ & $\begin{array}{c}\text { Interactions } \\
\text { with red wine }\end{array}$ \\
\hline rooibos & $2.7012^{\star * *}$ & $3.3068^{* * *}$ & -0.4001 \\
& $(0.3175)$ & $(0.3101)$ & $(0.3759)$ \\
organic & $0.7933^{* * *}$ & $1.8402^{* * *}$ & 0.0201 \\
& $(0.2637)$ & $(0.2834)$ & $(0.3089)$ \\
quality & $0.0641^{* * *}$ & $0.0907^{* * *}$ & -0.0020 \\
& $(0.0120)$ & $(0.0133)$ & $(0.0142)$ \\
price (in euro) & $-0.7276^{* * *}$ & $0.8832^{* * *}$ & 0.0564 \\
& $(0.1031)$ & $(0.0857)$ & $(0.1165)$ \\
\hline Model characteristics & & & \\
Log likelihood & -1833.271 & & \\
LR Chi ${ }^{2}$ & 1127.78 & & \\
No. obs. & 7,332 & & \\
$r($ respondents $)$ & 611 & & \\
$k($ parameters $)$ & 18 & & \\
\hline
\end{tabular}

Panel B - WTP estimates per bottle of wine, means in EUR

\begin{tabular}{lcc}
\hline & Red wine & White wine \\
\hline rooibos & $3.4287^{* * *}$ & $3.7125^{* * *}$ \\
& $(0.5210)$ & $(0.5154)$ \\
organic & $1.2122^{* * *}$ & $1.0904^{* * *}$ \\
& $(0.3654)$ & $(0.3581)$ \\
quality & $0.0926^{* * *}$ & $0.0882^{\star * *}$ \\
& $(0.0168)$ & $(0.0161)$ \\
\hline
\end{tabular}

Notes: ${ }^{*},{ }^{*}$, and ${ }^{* *}$ indicate significance at $10 \%, 5 \%$, and $1 \%$, respectively. Standard errors are provided in parentheses. All random parameters are fully correlated, with 1000 draws for simulations. Wald statistics for the equality test of the WTP means for each attribute between red and white wine is $0.16(p=0.6928)$ for rooibos; 0.07 ( $\mathrm{p}=0.7949)$ for organic; and 0.05 ( $\mathrm{p}=0.8316)$ for quality, indicating that mean WTP values are not statistically different for red and white wines at any convenient level. 
Table A2. Parameter estimates, MXL with headache interactions.

\begin{tabular}{lccc}
\hline & $\begin{array}{c}\text { Mean } \\
(\mathrm{s} . \mathrm{e})\end{array}$ & $\begin{array}{c}\text { SD } \\
(\mathrm{s} . \mathrm{e})\end{array}$ & $\begin{array}{c}\text { Interactions } \\
\text { with headache }\end{array}$ \\
\hline rooibos & $2.1259^{* * *}$ & $3.3019^{* * *}$ & 0.5800 \\
& $(0.3616)$ & $(0.2989)$ & $(0.4033)$ \\
organic & $1.0870^{* * *}$ & $1.8310^{* * *}$ & -0.3566 \\
& $(0.3124)$ & $(0.2673)$ & $(0.3490)$ \\
quality & $0.0525^{* * *}$ & $0.0895^{* * *}$ & 0.0193 \\
& $(0.0131)$ & $(0.0118)$ & $(0.0163)$ \\
price (in euro) & $-1.1687^{* * *}$ & $0.8493^{* * *}$ & 0.6915 \\
& $(0.1256)$ & $(0.0817)$ & $(0.1345)$ \\
& & & \\
\hline Model characteristics & & & \\
Log Likelihood & -1806.2427 & & \\
LR Chi & & & \\
No. obs. & 1066.11 & & \\
$r($ respondents) & 7,332 & & \\
$k$ (parameters) & 611 & & \\
\hline
\end{tabular}

Notes: ${ }^{\star}, * \star$, and ${ }^{* * *}$ indicate significance at $10 \%, 5 \%$, and $1 \%$. Standard errors are provided in parentheses. All random parameters are fully correlated, with 1000 draws for simulations.

Table A3. Parameter estimates, MXL with interactions on gender and race.

\begin{tabular}{|c|c|c|c|c|c|}
\hline & $\begin{array}{c}\text { Mean } \\
\text { (s.e) }\end{array}$ & $\begin{array}{l}\text { SD } \\
\text { (s.e) }\end{array}$ & Interaction with female & $\begin{array}{c}\text { Interaction with } \\
\text { African }\end{array}$ & $\begin{array}{c}\text { Interaction with } \\
\text { Caucasian }\end{array}$ \\
\hline rooibos & $\begin{array}{c}2.9056^{* * *} \\
(0.3938)\end{array}$ & $\begin{array}{c}3.2454^{\star * *} \\
(0.2993)\end{array}$ & $\begin{array}{c}-0.0740 \\
(0.3704)\end{array}$ & $\begin{array}{l}-0.7970^{*} \\
(0.4552)\end{array}$ & $\begin{array}{l}-0.3700 \\
(0.4453)\end{array}$ \\
\hline organic & $\begin{array}{c}0.1894 \\
(0.3242)\end{array}$ & $\begin{array}{c}1.8332^{\star * *} \\
(0.2701)\end{array}$ & $\begin{array}{l}0.7277^{\star *} \\
(0.3131)\end{array}$ & $\begin{array}{c}0.2429 \\
(0.3766)\end{array}$ & $\begin{array}{c}0.4770 \\
(0.3749)\end{array}$ \\
\hline quality & $\begin{array}{c}0.0577^{\star * *} \\
(0.0152)\end{array}$ & $\begin{array}{c}0.0913^{\star * *} \\
(0.0115)\end{array}$ & $\begin{array}{c}0.0014 \\
(0.0144)\end{array}$ & $\begin{array}{l}-0.0075 \\
(0.0179)\end{array}$ & $\begin{array}{c}0.0220 \\
(0.0173)\end{array}$ \\
\hline price & $\begin{array}{c}-0.6113^{\star * *} \\
(0.1220)\end{array}$ & $\begin{array}{c}0.9123^{* * *} \\
(0.0832)\end{array}$ & $\begin{array}{c}-0.1342 \\
(0.1193)\end{array}$ & $\begin{array}{c}-0.1761 \\
(0.1478)\end{array}$ & $\begin{array}{c}0.0902 \\
(0.1428)\end{array}$ \\
\hline \multicolumn{6}{|c|}{ Model Characteristics } \\
\hline Log likelihood & -1822.3397 & & & & \\
\hline LR Chi ${ }^{2}$ & 1090.13 & & & & \\
\hline No.obs & 7,332 & & & & \\
\hline$r$ (respondents & 611 & & & & \\
\hline$k$ (parameters) & 26 & & & & \\
\hline
\end{tabular}

Notes: ${ }^{*},{ }^{*}$, and ${ }^{* * *}$ indicate significance at $10 \%, 5 \%$, and $1 \%$, respectively. Standard errors are provided in parentheses. All parameters are fully correlated, with 1000 draws for simulations. 
Table A4. Parameter estimates, MXL with frequency of wine drinking interactions.

\begin{tabular}{|c|c|c|c|c|}
\hline & \multicolumn{2}{|c|}{ Random factors } & \multicolumn{2}{|c|}{ Fixed interactions } \\
\hline & $\begin{array}{c}\text { Mean } \\
\text { (s.e) }\end{array}$ & $\begin{array}{l}\text { SD } \\
\text { (s.e) }\end{array}$ & $\begin{array}{c}\text { Interactions with heavy } \\
\text { drinkers }\end{array}$ & $\begin{array}{c}\text { Interactions with light } \\
\text { drinkers }\end{array}$ \\
\hline \multirow[t]{2}{*}{ Rooibos } & $2.4721^{\star * *}$ & $3.4320^{* * *}$ & 0.2285 & -0.1926 \\
\hline & $(0.3131)$ & $(0.3101)$ & $(0.4321)$ & $(0.5180)$ \\
\hline \multirow[t]{2}{*}{ Organic } & $1.0082^{\star * *}$ & $1.6719^{* * *}$ & -0.0068 & -0.4929 \\
\hline & $(0.2443)$ & $(0.2835)$ & $(0.3439)$ & $(0.4081)$ \\
\hline \multirow[t]{2}{*}{ Quality } & $0.0641^{\star * *}$ & $0.0983^{* * *}$ & 0.0085 & 0.0109 \\
\hline & $(0.0116)$ & $(0.0117)$ & $(0.0170)$ & $(0.0204)$ \\
\hline \multirow[t]{2}{*}{ Price (in euro) } & $-0.8659^{* * *}$ & $0.9153^{\star * *}$ & $0.3545^{\star *}$ & 0.1548 \\
\hline & $(0.1055)$ & $(0.0861)$ & $(0.1389)$ & $(0.1649)$ \\
\hline \multicolumn{5}{|c|}{ Model characteristics } \\
\hline Log likelihood & -1826.8435 & & & \\
\hline LR Chi2 & 1109.95 & & & \\
\hline No. obs. & 7,332 & & & \\
\hline$r$ (respondents) & 611 & & & \\
\hline k(parameters) & 22 & & & \\
\hline
\end{tabular}

Notes: ${ }^{*},{ }^{*}$, and ${ }^{* * *}$ indicate significance at $10 \%, 5 \%$, and $1 \%$, respectively. Standard errors are provided in parentheses. All random parameters are fully correlated, with 1000 draws for simulations. 